\title{
ATTRACTANTS FOR ATHERIGONA SPP. INCLUDING THE SORGHUM SHOOTFLY, ATHERIGONA SOCCATA ROND. (MUSCIDAE:DIPTERA)*
}

\author{
K. V. Sisht Reddy, J. D. Skinnfr IIt and J. C. Davits \\ International Crops Research Institute for the Semi-Arid Tropus fIC RISATI. Patanchitu. \\ P() 502 324, A. P. Indal
}

(Recilited 14 Jamuari 1981)

\begin{abstract}
Abatract The use of fish meal and detergent water has been shown to be simple. economic and relatile for sampling of shootfly populatuons. Various mixtures of fish meal with other ingreduents were cvidu. ated. The most potent mixture was fish meal yeast ammonium sulphide, but generally fish meal alone was adequate and the most readily dvalable attractant. The attractance of tish meal was found of bo related to its degradation: it increased from the first to the third or fourth day, and then decreased The chemicals responsible for the attractance of fish meal have yet to be identified, hut in all probabality they may the the amines resutung from hiodegradation of the meal.
\end{abstract}

Ker Word. Sorghum shootly, attactants, fish meal

\section{INTRODUCTION}

SEVEral species of the genus atherigona are known to attack sorghum (Daviss of al., 1980); however. only Atherigona soccuta Rond. is economically important as a pest. This species is present in most of the Old World tropics except Australia. The insect attacks seedling sorghum in the first 45 weeks of growth. causing typical 'dead-heart' symptoms, and in years of high incidence can cause loss of plant population and yield, since tillers produced when the main shoot is killed are also destroyed and few panicles are produced. A closely related species, A. upproximula, is a potentially serious pest of pearl milet in India (JOTWANI and BITANi. 1978).

The dynamics of sorghum shootfly populations have been studied, usually by growing regular plantings of sorghum throughout the year, often in small contiguous plots (K 'ND' ef al.. 1971). This results in cross-infestation and often gives an erroneous impression of insect numbers and periods of peak incidence. There was a need for a simple trapping method to overcome these problems. Stakks (1970) used fish meal to attract shootflies into sorghum plots for increasing the efficiency of selection of sorghum resistant to the pest. and BARRY (1972) noted that ammonium sulphide was also attractive to the fly.

\section{MATERIALS AND METHODS}

During 1975 1976, several products. materials and chemicals were tested as shootfly attractants and attempts were also made to determine synergistic effects of different materials. Initial trials attempted to determine the efficacy of fish meal alone. In these, fish meal was moistened and placed in a mesh cylinder $(7.5 \mathrm{~cm}$ dia by $12.5 \mathrm{~cm}$ high) in square galvanized

- Submitted as $S$ and C A. No. 4, by the International Crops Research Institute for the Semi-Arid Tropics.

+Present address: 1740 North 59th Street, Lincoln. NE 68505 , U.S.A. metal pans $(60) \times 60 \times 7.5 \mathrm{~cm})$ litted wath lids which gave a gap of at least $7.5 \mathrm{~cm}$ between the lid and the top of the pan. The pans contained 201. of water plas a small amount $(100 \mathrm{~g})$ of detergent. The water was allowed to touch the eylinder to keep the fish meal moist. In later experiments other products such as ammonium sulphide, hrewers' yeast, and dead hearts were placed in the water. In the trials using ammonium sulphide. $20 \mathrm{ml}$ of a 2()$^{\prime \prime}$ "solution were used: brewers yeast was used at the rate of $20 \mathrm{~g}$ per trap. It was also found that 'swirling' the cylinder in the water of the trap and then allowing it to stand gave the best catches with fish meal as bait. In most trials, standard randomized block layouts were used, with traps separated by at least $25 \mathrm{~m}$. Traps were visiled every morning and flies, which tended to sink to the bottom. were scooped out with a galtue net for exam. ination in the laboratory to determine sex and species.

\section{RESULTS}

In the first experiment, pans containıng fish meal only were exposed at various sites at the ICRISAT Center. Results of a typical trial for 7 days exposure are given in Tahle 1. together with data at one location from control traps which tontained only water and detergent.

Shootflies were attracted to fish meal, but clcarly the site of the trap had a considerable influence on the size of the catch. Traps at sites where sorghum was growing in $\mathrm{BA}_{2}$, and the watershed, caught far more flies than others, while, even with fish meal, catches in uncultivated grassland areas were low. It was possible to analyze data from $\mathrm{BA}_{2}$, (pesticide-free black-soil area) on a paired-trap basis and this showed highly significant differences between the fish meal and the control (water + detergent) traps. Catches were heaviest in fish meal traps on the fourth day of exposure, indicating that biological degradation was a probable factor in attractance. 
K. V. Sesht: Redpy. J. D. Skinner II and J. C. Davies

Table 1. Mean total catch of shootflies. Atherigona spp. per trap over 7 days at the ICRISAT Center

\begin{tabular}{|c|c|c|}
\hline Site & No. of traps & Mean catch \\
\hline Unsprayed farm (BA 25 (fish meal) & 6 & 793 \\
\hline linsprayed farm $\left(\mathrm{BA}_{2}+\right)_{\text {(control) }}$ & $6^{\circ}$ & 27 \\
\hline Grassland (fish meal) & 12 & 40 \\
\hline Watershed (fish meal) & 4 & 613 \\
\hline
\end{tabular}

- Traps contained water and detergent only

Based on this work, a series of trials was carried out in late 1975 in which various components were added to fish meal. In the first trial, there were eight treatments replicated three times. Flies were collected at 2-day intervals for 14 days (Table 2).

Analysis of the data showed that catches with a combination of ammonium sulphide, yeast and fish meal were significantly better than all other treatments, and that, in general. treatments containing fish meal were attractive. Yeast and ammonium sulphide used atone were only slightly attractive, hut when combined there was a marked synergistic effect. The treatment containing ammonıum sulphide. yeast and tish meal was adopted as a standard attractant mixture for shootfly populatom studies at the ICRISAT Center.

Since there had been reports (PRalmian. 1971) that shootfly attack was heaver in fertilized fields, triats were also carried out in which ammonia, ammonium nitrate and urea were added to the standard treatment. All combinations reduced the catch compared with the standard mixture. The hest of these treatments, ammonia plus the standard, caught only half as many floes as the standard alone. Treatments containing ammonium nitrate. esther alone or in combination. were particuiarly poor

As sorghum 'dead hearts' prodisce a charateristic odor, their attractance to the shootfly was lested. A chi-square analysis of eatch over 7 days in March 1976 showed that a given volume of 'dead hearts' wats not as attractive to the shootfly as an equivalent volume of moist meal 'Dead hearts' were, however. attractive and on the day of maxinum attractance took 99 Ales compared with 207 taken by fish meal. traps in the experiment

Table : Mcan 2-day catch per trap of Arherigend spp over 14 dayn at the ICRISAT (enter (three replicates)

\begin{tabular}{|c|c|c|}
\hline Treatment & & Mean catch \\
\hline $\begin{array}{l}\text { Water } \\
\text { Wuter + yeast } \\
\text { Water + AS } \\
\text { Water + AS + FM } \\
\text { Water + FM } \\
\text { Water + yeast + FM } \\
\text { Water + AS + yeast } \\
\text { Water + AS + yeast + FM }\end{array}$ & $\begin{array}{l}\text { S. Em. } \pm \\
\text { L.S.D. }\{(0 .(0)\}\end{array}$ & $\begin{array}{r}2.44 \\
4.00 \\
4.00 \\
43.52 \\
96.76 \\
97.43 \\
178.05 \\
241.76 \\
31.47 \\
184.21\end{array}$ \\
\hline
\end{tabular}

$\mathbf{A S}=$ ammonium sulphide.

$\mathbf{F M}=$ fish meal.
As a follow-up to the work on addition of fertilizer to the meal, an experiment was conducted in which dead hearls and bullock dung. alone and in combination. were added to fish meal over a 14-day period in a three replicate randomized block trial in late March 1976. Dung was used. as flies had been ofserved to visit and apparently feed on dung pats the field, and also because it is a commonly use fertilizer. Overall catches in the experiment were low and the 'dead heart' plus fish meal combination was slightly inferior to fish meal alone (Table 3).

Catches were greatest in the lirst 4 days over all treatments. The attractant traps including tish meal were highly productse on the thard and fourth days. Dung appeared to have a depressing effect on the catches and there appears to be no other rattonal explanation for the very low catches in the fish meal dung dead-heart treatment. which catught very feu flen over the tirst 4 or 5 days. There was an interaction between treatments and days. which was largely explained by the very hegh attractance of the deadheart plus fish meal treatments in all replicates oser the first 3 days. Later. the treatment hecame less attracuve than the tish meal treatment alone.

\section{Nature of the attracternt in the mest}

A preliminary effort was made lo determine the basic charackeristacs of the chemicals responsible for the attractance of fish meal. Traps were bated with water. detergent powder, and a concentrate made from hoiled and unbosled fish meal. The concentral wats aged and fillered for the different treatment Results showed that traps in which the meal was not treated in any way and in which the minute pieces of fish meal were allowed to remain in the water were the most attractive and that when this solution was aged for 10 days it was less attractive and became even less so over the next 10 days of trapping. Solutons made from boiled meal were not very attractive either immediately or with aging, filtered or unfitered (Table 4).

It appears likely that the attractance of fish meal is due to biodegradation. A latin-square experiment was therefore carried out in which four treatments replicated four times were compared over 4 days. the period when fish meal had been shown to be most active. The treatments were fish meal alone. fish meal plus a biocide (aureofungin). water plus biocide. and water alone. It was demonstrated conclusively that addition of the biocide reduced the catches drastically. The possibility that biocide itself might repel fiies was not tested (Table 5). 
Table 3. Mean daily catch per trap of Atherigona spp. over 14 days at the ICRISAT Center on eight treatments (three replicates)

\begin{tabular}{|c|c|c|}
\hline Treatment & & Mean satch \\
\hline Dung + dead hearts & & 174 \\
\hline Water & & 1.76 \\
\hline Dung & & 2.31 \\
\hline Dead hearts & & 4.57 \\
\hline Dung + dead hearts + fish meal & & 560 \\
\hline Dung + fish meial & & 12.55 \\
\hline Dead hearts + fish meal & & 17.26 \\
\hline \multirow[t]{3}{*}{ Fish meal } & & 14.93 \\
\hline & $\mathrm{S} \mathrm{Em} \pm$ & 1.85 \\
\hline & L.S.D. $(1) .0 .5)$ & 9.56 \\
\hline
\end{tabular}

The eatch uas highest on the third day in tish meal traps and the analvis of data showed that all treatments nere markedly inferior to fish meal alone. The astdition of hiocide appeared to affect production of the elemical attractant.

The most likety hreakdown product from tish meal protem appeared to be an amine. and since skatolo ${ } \mathrm{C}_{4} \mathrm{H}_{4} \mathrm{~N}$ ) was available locally it was tesied. It proved to be attractse to the shootfly. hut inferior to fish meal in traps in adjacent experiments. In 12 traps. 339 shotfles werc caltght on the first day of exposure of the shatule The number fell to 122 an the second daly and $(x)$ un the third. by the fifth day. the eateh in the shatule traps was no greater than that in the control traps contamung detergent and water alone. A chicluare analysis conlirmed that skatole gave significanly hugher catches of shootfles than detergent water

\section{spesthat of the forh meal atractant}

In these trals, over $70,000($ shootflies were collected and representatuve samples of 2580 individuals were exammed from the catches of December 1975 and March April 1976 when most of the work was carried (rut It was clear that most of the flies attracted were from the genus therigona, hut that several species were represenled of the flies laken in December. $77^{\circ}$ " swere female, compared to $68^{\circ}$ " of those taken in April. Male 4 . wrout made up to $222^{\text {" }}$ of the sample taken in Decemher and almost $24^{\circ}$ "of that in April. A sigaticant propertion of the males trapped in April were A. falcafa. The overall mean trap eatch was over 4 times higher in December than in April.

\section{DISCUSSION}

The data show that fish meal is a powerful attractant for Muscod shootfles of the genus diherigene. The effectiveness of the fish meal can be greatly enhanced by addition of brewers yeast and anmotuum sulphide. but generally the use of tish meal alone would enable a simple and reliable assessment of shootfly populations. While syuare galvanized pans were used in these experiments almost any receptacle with a large surface area could be used. It was found in the course of the work that a lid was advantageous, as removal of the lid resulted in lower catches. The attractance of the medium increased to a peak on the third or fourth day and the mediun was predominantly attractive to females. There are indications from the report of (11 ARWATlk (1977) that there is also some selectivity within the lemales. It appears that young females are more attracted than older ones, and the work currently in progress (SISHu RHDDY of al. 1980; I NNITHaN, personal communication) indicates that the medium is most attratetive to females about to lay eges and that receptivity possibly varies with the stage of the female ovarian eycle. The males may blunder while in pursuit of females. While other products, notably 'dead hearts' and skatole, wete shown to be attractive for short periods they did not compare favorably with fish meal. The chemicals associated with the attractance of fish meal have not yet been identified, but they appear to be breakdown products from biodegradation of protein. This hypothesis received support from the fact that when a small frog died by chance in a water-and-detergent trap an apparently anomalous result of high catches

Table 4. Mean daily catch of Atherigrma spe. per trap over 14 days three replicates) on eight treatments

Treatment

1 10-day-old meal unhoiled unfiltered

11 20-day-old meal unboiled filtered 


\section{K. V. Seshl Reddy. J. D. Sxinner II and J. C. Davies}

Table 5. The effect of brocide on catch of Atherigona spp. in fish meal traps over 4 days (four replicates)

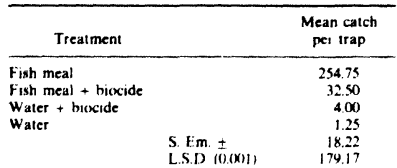

in this trap was obtained. The chemicals were not particularly persistent as was indicated by the experiments carried out on stored extract solutions. The use of a bocide resulted in far lower catches however. the possible effects of the brocide itself cannot be completely ignored. Boiling fish meal had a marked effect on the effectiveness of solutions subsequently made up, and this again indicates that the substances are probably associated with hiodegradation

Fish meal has now been used for several years at the ICRISAT Centet as a sampling tool and results from routine collections from traps will be compared with those obtained from small piots planted with sorghum at fortnightly intervals.

Achnowledermernts The authors wash to thank the staff of the Cereal Entomology division fur their cooperation and help in the course of these studies. and Di WuLAAM Ri:11), Pulse Entomologist. ICRISAT, for goung through the mantuscript.

\section{REFERENCES}

BAKRY D). (1972) Life history and other bologital notes on sorghum shootfly in Fast Africa In Control of Surghum
Shoorfly (E.d by JoTH ANI M G. and Yot 119 128. Oxfird \& IBH. New Delh.

Cilask UATH J R. (1977) Sistuhiom Shimhfly Rescurch. Taxinoms of tue Speries of Atherigona. Fourth Annual Report. 1976, ICIPE:, Nairobi

Davifs J. C. Sisint Rinis $K, V$ and Ribisy $Y, V . R$ (19K()) Species of shootflies reared from sorghum in Andhra Pradesh. India Pesi Articles Niews Summaries in press).

JOITHANI M G. and BITANI D. K 11978$)$ Crop pests and their control pearl millet Pesticides 12, 2030.

Kindi: G G. Pkim Kishort and Jutwani M. G. 119711 Scasonal incidence of sorghum shootfly Atherigenu turia seccata Rond. at (daipur (Rajasthan) In Inrestigations on Inse't Pests of Sarghum and Millets (Ed by PRaDHaN S.I. op 131137 Final Technical Report, 19651970. IARI. New Delhi

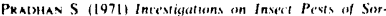
ahum and Millets. Final Technical Report. 19651970. IARI. New Delhi

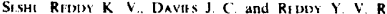
(1980) Montoring of the shootfly. Atheriyena spp. populatıons using tish meal batt traps (under preparation).

Siaras K J. (1970) Increasing infestations of the sorghum shoufly in experimental plots $J$ von. Ent 6.3. 17151716 